\title{
Aderentes e militantes: a participação político-partidária na era do Partido Cartel.
}



DOI 10.1590/1678-987316246004

\author{
Walter F. Nique Franz
}

\begin{abstract}
Resumo
O artigo analisa o estado da arte da literatura sobre as transformações nas formas de participação político-partidária produzida nas últimas décadas. Dois objetivos principais guiam nossa argumentação: (i) fornecer um panorama de referência que possa contribuir ao desenvolvimento de pesquisas sobre esta temática e (ii) atenuar a segmentação que caracteriza as distintas correntes analíticas. Revisando trabalhos publicados em revistas e livros anglo-saxões e franceses, comparamos suas problemáticas, as questões teóricas subjacentes, bem como os métodos de administração da prova utilizados. Destarte, identificamos a estruturação de dois campos de produção politológica que se comunicam pouco. De um lado, uma tradição "Political Science", mainstream, cujos estudos privilegiam uma abordagem sistêmica e comparada, apoiando-se em uma demonstração fundamentalmente estatística. De outro lado, uma tradição "Sociologie Politique" desenvolvida na França e cuja perspectiva de análise é internacionalmente pouco conhecida. Influenciadas pelo paradigma interacionista, suas pesquisas empregam o método sócio-etnográfico e redirecionam o foco de análise aos níveis meso e micro social. Fazendo um balanço crítico das principais contribuições de ambas as vertentes, apontamos algumas tendências atuais observadas pelos especialistas. Insistimos, particularmente, no potencial heurístico oferecido pelo enfoque da Sociologia Política para agregar novos elementos para a compreensão deste fenômeno.
\end{abstract}

PALAVRAS-CHAVE: participação política; militantismo; Partido Cartel; abordagem Political Science; abordagem Sociologie Politique.

Recebido em 20 de Agosto de 2015. Aceito em 7 de Setembro de 2015.

\section{Introdução}

\footnotetext{
1 Agradeço às sugestões propostas pelos pareceristas anônimos da Revista de Sociologia e Política, algumas delas foram integradas à versão final deste artigo; bem como aos colegas do seminário "Étudier les Partis Politiques" (CESSP-Paris 1) com os quais pude debater um working paper prévio a este texto. Expresso também meu reconhecimento ao apoio dado pela CAPES ao desenvolvimento desta pesquisa doutoral.
}

$\mathrm{D}$ urante as últimas décadas do século $\mathrm{XX}$, as sociedades ocidentais foram o palco de profundas transformações econômico-culturais que repercutiram significativamente no campo político ${ }^{1}$. A diversificação dos setores produtivos e a posterior crise da indústria fabril resultaram na desagregação dos meios operários que outrora haviam constituído uma das bases de recrutamento para os partidos de massa, especialmente os comunistas (Mischi 2013). Ao mesmo tempo, seguindo Inglehart (1977), a melhora do nível de vida e a elevação da taxa de escolarização da população, associadas ao desenvolvimento de meios de comunicação de massas, teriam produzido uma "revolução silenciosa". A passagem aos valores pós-materialistas conduziria as classes médias a uma preocupação crescente com questões não econômicas como a qualidade de vida. Sintomaticamente, a emergência de novos movimentos sociais, portadores de uma agenda contestatária afora das clivagens ideológicas tradicionais e promovedores de mecanismos de participação direta, ofereciam aos cidadãos formas alternativas de expressão política. Da conjugação destes fatores, os especialistas passaram a questionar a capacidade dos partidos em prover um enlace entre a sociedade e o Estado, advertindo para o risco de que fracassem em sua tarefa de manutenção do vínculo participativo (Lawson 1980; 1988).

Ao longo deste processo, os partidos foram adaptando suas estratégias organizativas e eleitorais, promovendo uma proposta programática menos ideo- 
${ }^{2}$ Ver por exemplo: Koole (1996), Kitschelt (2000) e Sawicki (2001).

3 Algumas exceções são Ysmal (1994) e Barboni (2010). logizada no intento de ampliar sua base de votos (Kirchheimer 1966) e recorrendo aos serviços profissionais de especialistas em marketing e em comunicação (Panebianco 1982). A tendência atual, de um declínio significativo da filiação partidária acompanhado pelo incremento da dependência ao financiamento público, foi teorizada como o advento do partido cartel (Katz \& Mair 1995). A difusão do modelo da cartelização entre núcleos de pesquisa, apesar das críticas despertadas ${ }^{2}$, consolidou-o como uma referência analítica incontornável, estimulando um revigoramento dos estudos sobre as estruturas organizativas e, no que nos concerne aqui, sobre a participação políticopartidária. De fato, conhecemos um importante desenvolvimento de programas de investigação e a multiplicação de estudos empíricos sobre a participação partidária, impulsados por distintos polos científicos. Também no âmbito da sociologia política francesa observa-se uma retomada estimulante, cujos trabalhos averiguaram o possível fim do militantismo (Ion 1997), interrogaram seu declínio ou mutação (Perrineau 1994), e analisaram o desengajamento (Fillieule 2005) e a desmobilização política (Matonti 2005). Entretanto, é importante ressalvar que nestes estudos, a recepção das hipóteses e do marco explicativo proposto pelo modelo do partido cartel não se traduziu por sua plena absorção. Mesmo quando a noção de cartelização é posta em foco, trata-se antes de esmiuçar o modelo para discutir sua consistência teórica e empírica (Aucante \& Dézé 2008) ${ }^{3}$.

Frente à diversidade de problemáticas, de enfoques e de resultados que, assentados nestas duas vertentes, emergem do esforço de renovação encetado nos últimos anos, parece-nos imprescindível realizar um balanço crítico do estado da arte das pesquisas sobre a participação político-partidária. Porquanto, o presente artigo responde a um duplo objetivo. Por um lado, procuraremos fornecer um panorama de referência, aportando tanto elementos teóricos específicos a este objeto como alguns exemplos empíricos, que possa contribuir ao desenvolvimento de trabalhos nesta área de conhecimento. Por outro lado, intentaremos atenuar a segmentação que caracteriza estas duas vertentes, ainda quando insistamos no potencial heurístico oferecido pelo enfoque sóciopolítico proposto pela escola francesa. Defendemos que em um contexto onde a perspectiva comparatista e quantitativa tende a predominar, abordar a participação qualitativamente, dialogando com a microssociologia e a antropologia, pode agregar novos elementos para a compreensão deste fenômeno.

\section{Delimitando os contornos dos campos de produção acadêmicos}

A literatura recente sobre a participação político-partidária encontra-se atravessada por embates epistemológicos e metodológicos que apontam à estruturação de dois campos de produção compartimentados. Na falta de uma melhor nomenclatura, elegemos denominá-los, por um lado, como uma tradição "Political Science", de inspiração anglo-saxônica e que se afirma como tendência mainstream e, por outro lado, como uma tradição de "Sociologie Politique" desenvolvida na França, que goza de menor influência internacional. Indubitavelmente, estas tradições não são homogêneas, estando atravessadas por debates e tensões entre correntes internas, alguns dos quais serão retomados ao longo deste ensaio. Entretanto, seus traços distintivos sustentam nossa esquematização, pois, embora se consagrem a explicar um mesmo fato social podendo, por vezes, repousar sobre problemáticas iniciais relativamente análogas, cada campo desenvolveu seus próprios protocolos de pesquisa, elaborou suas perguntas específicas, e dispõe de seus próprios universos de referências bibliográficas.

Logo de início, é preciso assinalar que as duas escolas incorporam em seus esquemas interpretativos tanto variáveis econômicas quanto sociais para a 
${ }^{4}$ Bem entendido, esta classificação apenas faz sentindo para o objeto deste artigo, onde inclusive poderíamos falar de uma sociologia do militantismo. Em outras áreas temáticas (teoria do Estado, políticas públicas, comportamento eleitoral) nutrem-se distintos diálogos com as escolas anglo-saxônicas.
5 Os questionários são aplicados por ocasião de eventos partidários como congressos e escolas de verão. Em média, trabalha-se com uma população de 200 ou 300 casos, isto é, cerca de $20 \%$ dos participantes. explicação do fato político. Neste sentido, o que lhes distingue é o ângulo de abordagem privilegiado, ou seja, se estão posicionadas em um paradigma macrossocial (voltado à busca de regularidades nas estruturas sociais) ou microssocial (centrado nas interações e nas lógicas sociais). Como veremos, a dimensão meso-social é tida em consideração por ambas as tradições.

Acordando maior relevância às explicações sistêmicas, os trabalhos da $\mathrm{Po}$ litical Science privilegiam a exploração das dimensões macro e, em menor medida, mesossociais. O recorte do objeto é estabelecido no conjunto dos aderentes (party memebership), a esfera mais ampla da participação partidária, a partir do qual obtêm informações acerca dos níveis de ativismo. Seu instrumento de administração da prova é fundamentalmente estatístico. Explorando dados agregados em estudos comparativos, os pesquisadores encontram evidências do declínio da filiação partidária nas democracias avançadas. Eles interrogam-se sobre as transformações subsequentes no modo de organização dos partidos e sobre sua capacidade em assegurar a função de enlace entre a sociedade e o Estado (political linkage). A partir do começo dos anos 1990, este programa de investigação tem sido desenvolvido até o ponto de estabelecer-se como a tendência dominante na análise deste objeto, um empreendimento cuja amplitude é indissociável da dinâmica do campo de produção científico. Por um lado, através do apoio decisivo obtido junto a organismos como a American Political Science Association (APSA) e o European Consortium for Political Research (ECPR). Por outro lado, pelo lugar ocupado pela revista Party Politics que, desde seu lançamento em 1995, constituiu-se na principal referência internacional no estudo de partidos políticos.

As pesquisas em Sociologie Politique 4 concentram-se em um subgrupo do universo dos aderentes, aquele dos membros ativos ou militantes. Defendendo o desenclausuramento da disciplina, esta escola promove um diálogo entre a ciência política com outras ciências sociais, particularmente a sociologia, a antropologia e a história, das quais se apropria de instrumentos teóricos e metodológicos. Influenciados pelo paradigma interacionista, estes estudos partem da premissa de que as transformações macroestruturais não produzem efeitos automáticos sobre a realidade social, procurando compreender a maneira pela qual elas são filtradas e traduzidas pelas organizações partidárias e, ao mesmo tempo, como são ajustadas as disposições dos indivíduos que as compõem. Trata-se então de analisar as práticas militantes e o trabalho de politização empreendido pelos partidos e, ao fazê-lo, de redirecionar o foco de análise aos níveis meso e microssocial. Em termos metodológicos, é preciso destacar que o recurso a dados quantitativos não é abandonado. Entretanto, posto que as amostras contêm um número restrito de indivíduos, os resultados recolhidos são submetidos à análise estatística descritiva (raramente inferencial ou fatorial $)^{5}$. Sobretudo, a caixa de ferramentas empregada é mais ampla incluindo o trabalho em arquivos, a realização de entrevistas e a observação, privilegiando para tanto a imersão prolongada no terreno para a coleta de material empírico (método sócio-etnográfico). A fim de balizar esta tradição, podemos identificar o Centre de Recherches Politiques de la Sorbonne (CRPS) como uma de suas principais instituições de referência, bem como a revista Politix como seu veículo de difusão (Quadro 1).

Enfim, os dois campos distinguem-se nitidamente na maneira como, teoricamente, constroem seu objeto. De forma geral, a questão da participação pode ser abordada sob três ângulos de análise, interrogando sua intensidade e sua natureza, bem como a função exercida pelos aderentes. A problemática da intensidade abarca tanto uma preocupação taxionômica voltada à classificação dos diferentes níveis de participação, dos círculos concêntricos de Duverger (1951) às categorias de filiação partidária de Scarrow (2015), como uma preocupação de mensuração estatística da assistência aos distintos tipos de 
Quadro 1 - Principais características das tradições em estudo

\begin{tabular}{|c|c|c|}
\hline & $\begin{array}{c}\text { Political Science } \\
\text { (tendência mainstream) }\end{array}$ & $\begin{array}{l}\text { Sociologie Politique } \\
\text { (tendência minoritária) }\end{array}$ \\
\hline Metodologia principal & Quantitativa & Qualitativa \\
\hline \multirow[t]{3}{*}{ Procedimentos quantitativos } & $\begin{array}{l}\text { Mensuração da taxa de adesão em séries } \\
\text { temporais }\end{array}$ & $\begin{array}{l}\text { Quantificação do número de filiados } \\
\text { (eventualmente) }\end{array}$ \\
\hline & $\begin{array}{l}\text { Surveys de grande envergadura } \\
\text { endereçados a amostras de aderentes }\end{array}$ & $\begin{array}{l}\text { Aplicação de questionários a uma } \\
\text { população circunscrita (aderentes de um } \\
\text { único partido, de uma federação aos } \\
\text { militantes) }\end{array}$ \\
\hline & $\begin{array}{l}\text { Tratamento estatístico: análise } \\
\text { descritiva e fatorial (linear, } \\
\text { multivariada) }\end{array}$ & $\begin{array}{l}\text { Tratamento estatístico: análise } \\
\text { descritiva. Eventualmente: análise de } \\
\text { redes, análise de correspondências } \\
\text { múltiplas (ACM) }\end{array}$ \\
\hline Procedimentos qualitativos & $\begin{array}{l}\text { Descrição de evoluções históricas das } \\
\text { organizações partidárias, de suas fontes } \\
\text { de financiamento e do recrutamento de } \\
\text { aderentes }\end{array}$ & $\begin{array}{l}\text { Pesquisas sócio-etnográficas } \\
\text { (observação entrevistas entrevistas } \\
\text { bibliográficas); imersão prolongada no } \\
\text { terreno; descrição de evoluções } \\
\text { históricas }\end{array}$ \\
\hline Unidade de medida & $\begin{array}{l}\text { Aderentes (party membership) } \\
\text { secundariamente ativistas }\end{array}$ & Militantes (membros ativos) \\
\hline Perspectiva analítica & Funcionalista e/ou compreensiva & Interacionista, compreensiva \\
\hline Escala & $\begin{array}{l}\text { Comparativa (em nível nacional e entre } \\
\text { sistemas partidários) }\end{array}$ & $\begin{array}{l}\text { Localizada/ comparativa (a nível } \\
\text { nacional) }\end{array}$ \\
\hline \multirow[t]{2}{*}{ Hipóteses principais } & $\begin{array}{l}\text { Marginalização dos aderentes ou dos } \\
\text { ativistas; erosão do political linkage; } \\
\text { erosão do enraizamento social dos } \\
\text { partidos }\end{array}$ & $\begin{array}{l}\text { Continuum entre práticas políticas } \\
\text { institucionais e extra-institucionais. } \\
\text { Militantismo plural, imbricações entre o } \\
\text { jogo social e o jogo político }\end{array}$ \\
\hline & $\begin{array}{l}\text { Nova modalidade: militante } \\
\text { distanciado, cibermilitante }\end{array}$ & $\begin{array}{l}\text { Nova modalidade: militante } \\
\text { intermitente }\end{array}$ \\
\hline Dimensão explicativa & $\begin{array}{l}\text { Sistêmica/macrossocial; e em menor } \\
\text { medida meso-social; busca de } \\
\text { regularidades generalizáveis }\end{array}$ & $\begin{array}{l}\text { Meso e microssocial; explicações } \\
\text { processuais; práticas militantes e } \\
\text { sociabilidades; construção de } \\
\text { identidades; trajetórias e } \\
\text { multiposicionalidade }\end{array}$ \\
\hline Revista de referência & Party Politics & Politix \\
\hline
\end{tabular}

Fonte: $\mathrm{O}$ autor.

atividades. No que concerne à natureza, os estudos dirigem-se às lógicas da participação e à formação de identidades, enquanto os questionamentos funcionalistas visam compreender o papel que os partidos incumbem aos seus aderentes. Embora lhes seja acordada uma ênfase variável, estas três dimensões são desenvolvidas tanto pela Political Science quanto pela Sociologie Polique. Primordialmente, a clivagem teórica entre as duas correntes situa-se na delimitação do perímetro do objeto de investigação.

Na esteira dos trabalhos de Lawson (1980; 1988), referenciados explicita ou tacitamente, a tendência mainstream contempla um sistema de formas de conexão política ancorado em três binômios paralelos: indivíduos e organizações políticas, organizações políticas e Estado, indivíduos e Estado. Dentro desta perspectiva, o partido instaura um vínculo participativo (participatory linkage) quando

"ele serve de agência através da qual os cidadãos podem eles mesmos participar no governo. Eles fazem isso por meio da formulação do programa partidário, 
escolhendo seus candidatos (ou tornando-se eles mesmos candidatos), e, mais importante, considerando seus representantes eleitos como responsáveis pelo programa partidário" (Lawson 1988, p.16).

Se este esquema tem o mérito de avançar em um esforço de conceptualização do vínculo político participativo, ele termina, porém, erigindo um marco analítico demasiado rígido. Por um lado, insistindo em uma separação funcional da fabricação de vínculos políticos, os autores apontam mais para as relações de concorrência entre partidos políticos, grupos de interesses e movimentos sociais, que para as interdependências suscetíveis de serem tecidas entre eles (Kitschelt 1990). Por outro lado, a predominância do enfoque institucional, circunscrevendo o perímetro às modalidades de participação organizativas, põe em relevância apenas o caráter partidário da participação. Ora, Verba e Nie (1972) demonstraram precisamente a multiplicidade de canais de participação política e a influência exercida pelo pertencimento a organizações não partidárias nos processos de politização. Como, então, ignorar a produção de enlaces políticos com a sociedade quando existem relações consolidadas entre partidos políticos e sindicatos, grupos patronais, cooperativas, grupos religiosos, ONGs ou movimentos sociais? Ou quando um partido incorpora à sua agenda causas defendidas por estas organizações? Como negligenciar o estabelecimento de vínculos políticos quando militantes partidários contribuem à politização das reivindicações de um movimento social, sem que seus membros adiram ao partido? Ou ainda, quando ex-militantes partidários se convertem em um movimento social levando consigo valores e percepções acerca do mundo social que foram incorporados ao longo de sua socialização política?

Para dar conta deste "trabalho multiforme que operam os partidos para consolidar seus susténs ou para conquistar novos, para impor problemáticas ou para difundir certas representações" (Sawicki 2011, p.32), a Sociologie Politique fornece outro marco teórico. Recentrando sua lente em direção ao entorno partidário (milieu partisan, Sawicki 1997; Lagroye et al., 1976) esta perspectiva incorpora os meios sócio-políticos como variável explicativa da modelagem tanto da organização quanto das formas de participação (Combes 2004; Fretel 2011; Mischi 2013). Isto não implica denegar a diferenciação funcional entre organizações especializadas, mas reconhecer que estabelecem entre si múltiplas relações (tanto de cooperação quando de concorrência). Incontestavelmente, partidos, sindicatos, associações e movimentos sociais possuem objetivos próprios, exibem distintos graus de institucionalização, estando inseridos em universos sociais diferenciados, mais ou menos autônomos (campo político, campo sindical, espaço de movimentos sociais). As fronteiras organizativas existem, mas em cada partido elas apresentam graus variados de permeabilidade. Por esta razão, as transferências produzidas entre estes espaços são ambivalentes, podem provocar tensões, e engendram problemas práticos aos atores (Mathieu 2012) ${ }^{6}$.

${ }^{6}$ Em termos sistémicos, uma perspectiva que permite integrar a especialização funcional às interações entre organização setoriais e que, ao mesmo tempo, fornece uma alternativa ao modelo da cartelização (com sua hipótese de desconexão entre os partidos e a sociedade) é a de pensar em termos de campo político (Bourdieu 2000) e de um espaço de movimentos sociais (Mathieu 2012).
Esta distinção traz importantes repercussões na maneira de pensar as formas da participação. Não se restringindo a captar a conexão entre partidos e a sociedade exclusivamente em termos de adesão partidária e de maximização de votos (Favre \& Fillieule 1994), os pesquisadores tomam em consideração outras formas de envolvimento político vinculadas aos partidos, mas que não estão limitadas à suas fronteiras organizativas. Assim sendo, o exercício da participação político-partidária é entendido em um continuum entre ações institucionais e extrainstitucionais ${ }^{7}$.

Bem entendido, este marco teórico não pretende contestar as robustas evidências do declínio da adesão partidária. Tão pouco, a mudança de enfoque não evoca nenhum "redescobrimento" do militantismo. O que sim, cremos, é que ele provê um ferramental heurístico para que possamos adquirir uma 
compreensão mais aguçada das transformações em curso nas formas de participação político-partidária, em um contexto de inserção dos indivíduos em múltiplos espaços sociais e de proliferação da oferta participativa.

\section{O papel dos aderentes na era do partido cartel}

${ }^{7}$ Dessa maneira, fazemos aqui um recorte da problemática da participação política, na órbita partidária, sem, contudo, deslocar-se em direção a outras formas como o comportamento eleitoral. Para citar um exemplo de estudo macrossocial provido pela Political Science no qual se levam em consideração estes múltiplos espaços de ativismo, remetemos a Kitschelt (1990) e Norris (2002).

${ }^{8}$ Este ferramental também inclui o cálculo do quociente entre o número de ativistas e o eleitorado (A/E) que demonstra o grau de penetração dos partidos na sociedade, ou ainda o quociente entre o número de ativistas e de membros (A/M) que mede a dinâmica interna das organizações. Porém, quando estes índices são agregados e comparados entre distintos países, os resultados mostram tantas variações que não permitem discernir uma tendência geral (Heidar \& Saglie 2003, p.764).

9 Katz (1990) evoca os danos eleitorais sofridos pelo Labour Party e pelo SPD alemão em virtude da adoção de uma orientação programática mais à esquerda em resposta as demandas de seus aderentes.

${ }^{10}$ Outros autores insistem sobre a importância da legitimidade concedida pelos membros partidários sem, contudo, cair em uma visão excessivamente utilitarista (Seyd \& Whiteley 2004; Young \& Cross 2002).

${ }^{11}$ Esta questão preocupa menos a Sociologie Politique, mais interessada nos processos de ativação da oferta militante e nos conflitos organizativos decorrentes.
Os trabalhos pioneiros de R. Katz e de P. Mair (Katz 1990; Katz \& Mair 1992; 1994) concorreram à objetivação do desmoronamento da taxa de filiação partidária nas democracias consolidadas, estimulando um vasto programa de pesquisas. Na continuidade, diversos especialistas empenharam-se em refinar os indicadores para captar o descenso da adesão, pela extensão das séries temporais e do universo de países em comparação (Scarrow 2000; Van Biezen, Mair \& Poguntke 2012); pela medição de efeitos diferenciais entre tipos de partidos (Delwit 2011); ou ainda pelo emprego de análises multivariadas com objetivo de identificar as flutuações nas trajetórias individuais dos partidos (Kölln 2014) ${ }^{8}$. Estas evidências nutriram um esforço de teorização no seio do qual foram formuladas uma série de hipóteses acerca da função exercida pelos aderentes na atual conjuntura.

De acordo com Katz (1990), estamos em meio a uma profunda redefinição do papel dos filiados. Os partidos tornaram-se organizações de líderes deixando de serem organizações de cidadãos. Os aderentes são substituídos, por um lado, pela televisão como canal de informação e de comunicação e, por outro, pelas subvenções públicas como fonte de financiamento, traços estes que caracterizam o partido cartel. Aliás, os aderentes podem, inclusive, ser daninhos para os interesses eleitorais, constringindo as decisões estratégicas dos dirigentes, especialmente quando é sabido que os filiados não são necessariamente representativos do universo do eleitorado partidário9. Manter aderentes também consome recursos organizativos. Como sublinham Seyd e Whiteley (2004), recrutar e entreter os vínculos exigem investimentos na realização de campanhas, na manutenção dos fichários, e por vezes na prestação de serviços. Neste contexto, alguns autores têm sustentado a hipótese da marginalização dos filiados que, doravante desnecessários, seriam ignorados (Katz 1990) e supérfluos (Bille 1994). Destarte, no modelo do partido cartel o papel atribuído aos filiados seria limitado a conferir uma áurea socialmente legítima às empresas políticas dando uma aparência de que o partido preserva uma conexão com a sociedade $^{10}$, o que explicaria por que os dirigentes continuariam a insistir no recrutamento apesar dos contratempos e dos custos decorrentes.

Contudo, esta interpretação está longe de ser um consenso entre os especialistas da própria vertente mainstream ${ }^{11}$. Scarrow (2000) elabora uma hipótese contrária, sugerindo que o declínio no número de membros poderia ser compensado pela intensificação da participação dos afiliados. De tal forma, os níveis de ativismo poderiam aumentar enquanto o tamanho da seção diminui, posto que as necessidades em termos de trabalho partidário são frequentemente fixas (quer dizer, as seções necessitam de um número especifico de permanentes e também de candidatos para as eleições locais). Ainda que as conjecturas de Scarrow não sejam confirmadas por dados empíricos, elas têm o mérito de pôr em relevo o fato de que, apesar das transformações atuais, os partidos podem continuar a necessitar dos aderentes para toda uma série de tarefas.

Com efeito, diversos autores acordam sobre o fato de que os aderentes, em graus variados, continuam a preencher certo número de funções não desprezíveis no interior dos partidos, para além da legitimidade que eles conferem a estes (Mair 1994; Seyd \& Whiteley 2004). Em primeiro lugar, mesmo que as subvenções públicas tenham se tornado instrumentos inelutáveis do financiamento partidário, as contribuições dos filiados não foram completamente suplantadas. Na Europa, os exemplos contrastados da Irlanda e da Noruega 
${ }^{12}$ A emenda de 1994 na Lei de Partidos Políticos introduz o financiamento público anual dos partidos sob um duplo critério: (a) o desempenho eleitoral (votos recebidos); (b) o volume de doações recebidas. Esse dispositivo pretende valorizar o enraizamento social dos partidos e o vínculo com os aderentes (Alemanha 1994).

13 Calculado pelo autor a partir do relatório da CNCCFP (2012).

14 "Television has become the dominant source of political information and the dominant channel of communication from elites to the public, with the party meeting, the party canvasser, the party press, all supplanted in importance by party leader speaking directly to his or her supporters on the small screen" (Katz 1990, p.145). aparecem como atípicos: em média, as cotizações representam, respectivamente, $80 \%$ e $10 \%$ das receitas partidárias (Mair 1994, p.14). Em boa parte dos países estes recursos respondem pelo quarto ou o quinto dos orçamentos. $\mathrm{Na}$ Alemanha não apenas elas constituem 20\% dos ingressos da CDU e $25 \%$ para o SPD (Detterbeck 2008) como o número de aderentes é tido em conta na distribuição do fundo partidário ${ }^{12}$. Assim, os subsídios alocados como complemento de doações corresponderam, em 2007, a 52\% da dotação acordada ao CDU e a 49\% do SPD (Alemanha 2007). Na Dinamarca as contribuições dos aderentes variam entre $10 \%$ para o CD e $20 \%$ para a SD (Bille 1994) em quanto que na França, em 2011, levando em consideração as cotizações dos filiados e as doações feitas por simpatizantes, a proporção eleva-se a 25\%, sendo $30 \%$ para a UMP e $20 \%$ para o PS $^{13}$.

Em segundo lugar, mesmo admitindo que a televisão possa substituir a antiga imprensa partidária como veículo de comunicação, parece abusivo deduzir que, da mesma forma, os aderentes seriam permutados pelo "vínculo direto" que através da "telinha" se estabeleceria entre os líderes e os eleitores. Esta hipótese, enunciada por Katz (1990) ${ }^{14}$ consente alguns pressupostos fortemente objetados por estudos empíricos portando sobre o comportamento eleitoral. Por um lado, ela supõe que o eleitorado seja interessado por questões e por programas políticos e, sobretudo, que seja politicamente competente para apreender as informações, compreender as problemáticas em jogo e de transformá-las em intenção de voto (Gaxie 1978; 1993). Por outro lado, tal suposição assume uma eficácia do processo de transmissão da mensagem política pela mídia que não está comprovada. Esta ideia foi de partida contestada por Lazarsfeld, Berelson e Gaudet (1968) e a escola de Columbia. Recentemente, especialistas em comunicação política vêm demonstrando que a transmissão de informações procede de maneira indireta (two-step flow) apoiando-se na intervenção de mediadores, líderes de opinião que retraduzem as mensagens ao público (Popkin 1994). Ora, é precisamente neste nível que os aderentes podem exercer uma influência, reforçando o discurso partidário: "as pessoas claramente dependem da mídia de massas, em particular da televisão, para uma boa parte da sua informação política. Mas também é evidente que as discussões faca-a-face com amigos, familiares e com colegas de trabalho desempenham um papel importante influenciando as ideias políticas" (Seyd \& Whiteley 2004, p.362). Para Scarrow, os aderentes atuariam com embaixadores na comunidade podendo, inclusive, "ser muito mais efetivos que as campanhas midiáticas centralizadas para a construção de enlaces com a cidadania, e transmitindo a impressão de que o partido é mais do que a empresa de uma elite política" (Scarrow 2000, p.84). Em definitivo, os indícios apontam que o êxito da comunicação política se assenta na conjunção de um acesso à mídia com a ação de aderentes que, no terreno, propagam as mensagens em suas redes de sociabilidade.

Em terceiro lugar, para além destes debates maiores da literatura, não podemos ignorar outras funções exercidas pelos filiados e que são particularmente pertinentes em períodos eleitorais. Eles participam, juntamente com outros atores, no trabalho de agregação de interesses e de formulação de políticas, transferindo inputs desde seus grupos de pertencimento até as elites partidárias (Seyd \& Whiteley 2004; Pedersen 2006). Eles constituem uma base de votos que, mesmo se sua proporção no eleitorado vem sendo reduzida, apresenta a vantagem de estar consolidada. Um trunfo ainda mais importante quando de eleições locais e europeias à medida que são escrutínios marcados pelo fraco comparecimento às urnas (Scarrow 2000; Seyd \& Whiteley 2004). Eles ainda constituem uma reserva para o recrutamento, particularmente importante no nível local (menos cobiçado pelos professionais) seja para ocupar postos burocráticos, seja para preencher as listas eleitorais (Scarrow 2000). Enfim, os aderentes guardam seu valor como recursos humanos no momento da 
implementação das campanhas eleitorais, realizando um trabalho corpo-acorpo de mobilização de eleitores em complemento às campanhas centralizadas e suas custosas técnicas de comunicação (Mair 1994; Seyd \& Whiteley 2004).

Um indício desta importância relativa dos aderentes consistira na tendência à sua maior integração às organizações partidárias através da adoção de procedimentos consultivos. Todavia, esta democratização intrapartidária modifica a relação entre os partidos e suas bases ao favorecer uma atomização da relação entre o partido e seus membros, ao mesmo tempo diluindo o poder das elites intermediárias e dos militantes (mais ativos, porém menos numerosos). Assim sendo, Mair reformula a hipótese inicial de Katz, explicando que um processo de marginalização estaria em marcha, mas abrangendo apenas os grupos de ativistas, "uma camada mais estorvante" e menos "dócil" que se veria apartada na tomada de decisões internas (Mair 1994, p.14).

De todos os modos, claro está que este debate funcionalista responde a apenas uma das facetas do problema da participação partidária. Por certo, em meados dos anos 1990, no âmago da Political Science, o desenvolvimento desta agenda de pesquisas conhece uma bifurcação. Enquanto um núcleo de investigadores aferia os instrumentos de medida e de análise do declínio da adesão, outros especialistas debruçavam-se sobre o nível intrapartidário.

\section{Abrindo a caixa preta da participação partidária: níveis de participação e práticas militantes}

\footnotetext{
15 P. Seyd e P. Withley tiveram um papel central neste empreendimento, tanto pela relevância de seus trabalhos seminais sobre os partidos ingleses, como pela organização de um workshop no ECPR Research Session de 1995 (em Troms $\varnothing$, Noruega) voltado a essa temática, e que resultou na publicação de um número especial de Party Politics, em 2004 (v.4, n.10).
}

No âmbito da Political Science, uma segunda onda de trabalhos redirecionou o foco das pesquisas em direção ao nível meso-social a fim de lançar luzes sobre as modalidades de envolvimento dos aderentes ${ }^{15}$. Em muitos aspectos, esta abertura da "caixa preta" da participação partidária constitui o principal ponto de convergência entre as escolas mainstream e a francesa, porquanto ambas se propõem a examinar a atividade dos aderentes na vida interna dos partidos, e ambas também empregam técnicas estatísticas. Porém, enquanto a perspectiva compreensiva da Political Science prioriza uma abordagem comparativa, buscando avaliar as razões que levam à adesão e os níveis de participação às atividades internas, a Sociologie Politique investe em estudos interacionistas de corte monográfico para restituir as práticas militantes, as retribuições ao engajamento e a formação de identidades partidárias.

IV.1. Motivações: por que aderir?

Dada a tendência à "desideologização" dos partidos, identificada por Kirchheimer (1966), e sua crescente profissionalização (Panebianco 1982; Katz \& Mair 1995), seria razoável supor um deslocamento das motivações à adesão, passando-se das incitações ideológicas em direção às incitações seletivas. Entretanto, os resultados obtidos invalidam esta hipótese ressaltando, ao contrário, a importância da dimensão ideológica/programática entre as motivações a filiar-se a um partido, a participar das atividades internas, e a permanecer. Young e Cross (2002) demonstram que nos partidos canadenses a crença no programa e na ideologia é um fator de vinculação mais significativo do que as incitações seletivas. As pesquisas de Wauters (2010) e de Van Haute (2012) sobre os partidos belgas apontam no mesmo sentido. As motivações ideológicas e instrumentais, ou seja, a possibilidade de influenciar as decisões programáticas ou as políticas governamentais, aparecem como uma razão central para a participação dos aderentes. Na Noruega, as motivações políticas são majoritariamente alegadas nos surveys, tendo progredido inclusive de 50\% (1991) a $58 \%$ (2000), o que permite aos autores sustentarem que "nós não encontramos nenhuma evidência de despolitização dos partidos ou de marginalização dos 
seus membros" (Heidar \& Saglie 2003, p.783). Uma conclusão cuja validade pode incontestavelmente ser estendida aos demais casos supracitados.

As evidências recolhidas lembram que a obtenção de benefícios materiais não é o único interesse que induz à adesão partidária, contrapondo-se à visão utilitarista inspirada pelos modelos do comportamento racional (Downs 1957; Olson 2011). No entanto, a importância do componente ideológico explica-se também pela unidade de análise escolhida e pelo método de investigação. Precisamente, o componente ideológico torna-se mais importante pelo tipo de participação de baixa intensidade que caracteriza a globalidade dos aderentes. As incitações seletivas tornar-se-iam mais importantes na medida em que se consagre tempo e esforço à causa.

\section{IV.2. Niveis de participação nas atividades internas}

${ }^{16}$ Gaxie apoia-se no exemplo de três países (Noruega, Grã-Bretanha e Finlândia) que, nesta época, destacaram-se pelo elevado número de aderentes partidários. Scarrow comparou a proporção de ativistas dentre os membros (A/M) em 12 democracias industrializadas.

17 Promédio de respostas "frequentemente" e "algumas vezes".

${ }^{18}$ A proporção é relativamente importante se comparada com outros partidos. No entanto, a escala de participação fixada em cinco anos é demasiado abrangente como critério.

\footnotetext{
${ }^{19}$ Decepcionados pela orientação política do governo, cerca de $60 \%$ dos 150 mil aderentes do PS não haviam renovado sua adesão às vésperas do Congresso partidário (Le Parti Socialiste vise les... 2014).
}

Entre o universo de aderentes, é sabido que apenas uma porcentagem reduzida participa ativamente na vida interna dos partidos. Gaxie (1977, p.143) outrora situou esta taxa em torno de 3\%, enquanto as estimativas de Scarrow (2000, p.95) variam entre $10 \%$ e $45 \%{ }^{16}$. Trabalhos recentes, apoiando-se em bancos de dados constituídos por surveys, esboçam um panorama mais preciso da maneira como os aderentes participam nas atividades partidárias.

Na Bélgica, embora três quartos dos filiados mantenham contatos regulares com suas seções locais ${ }^{17}$, a esmagadora maioria (80\%) dedica-lhes menos de cinco horas mensais, enquanto que dois em cada três aderentes abstêm-se das reuniões locais (Van Haute 2012). Na Dinamarca, um pouco mais de 50\% dos membros de todos os partidos parlamentários assistiram às reuniões em nível subnacional ao longo dos cinco anos precedentes à pesquisa, mas menos da metade declararam ter participado de atividades socioculturais organizadas por seu partido ${ }^{18}$. Em contrapartida, no caso dinamarquês, o grau de implicação enfraquece significativamente no momento das campanhas eleitorais: cerca de $40 \%$ dos aderentes assistiu a um meeting público enquanto que somente um quarto distribuiu panfletos e um quinto fixou cartazes. Ao que parece, os filiados dinamarqueses privilegiam uma modalidade de participação mais comunicativa e menos presencial, dado que $74 \%$ afirma ter discutido política com não-aderentes e $67 \%$ ter encorajado a votar pelo seu partido (Pedersen 2006).

Não obstante, o caráter sincrônico destes estudos limita a amplitude das conclusões que podem ser tiradas. É possível, como sugere Katz, que assistamos a uma marginalização dos aderentes e que, em consequência, sua passividade acompanharia o declínio da taxa de adesão. Mas as outras hipóteses permanecem igualmente razoáveis. Poderíamos indagar se não se trata de uma situação conjuntural na qual um evento marcante, acarretando uma decepção com respeito à política, provocaria uma diminuição da intensidade do ativismo: um escândalo de corrupção implicando grandes partidos (como o revelado em Itália pela operação mani pulite no início dos anos 1990), uma crise econômica prolongada ou ainda a chegada ao poder de um partido (ou de uma coalisão) de oposição em um contexto de uma estreita margem de manobra para a implementação do seu programa de governo (como foi o caso do PS na França a partir de 2012) ${ }^{19}$. Igualmente, podemos supor que se trate de uma tendência de longo prazo na qual o fraco nível de participação de seus membros consistira, simplesmente, em uma característica inerente às empresas partidárias. Não dispondo de pesquisas diacrônicas, a verificação destas hipóteses torna-se impossível.

Estudos longitudinais, possibilitando elucidar as transformações e continuidades na participação dos aderentes, parecem mais adaptados para captar estas evoluções. Neste sentido, a pesquisa conduzida por Heidar e Saglie (2003) sobre a evolução da participação nos partidos noruegueses durante os anos 1990 
20 Mensura da frequência da assistência dos membros aos eventos partidários durante o ano precedente à sondagem.

21 Nos últimos 30 anos, os partidos noruegueses perderam mais de $60 \%$ de seus efetivos, enquanto que o quociente $\mathrm{M} / \mathrm{E}$ recuou 10 pontos, passando de $15,35 \%$ em 1980 a $5,04 \%$ em 2008. A título comparativo, os partidos belgas perderam cerca de $30 \%$ dos aderentes; os partidos dinamarqueses $40 \%$ enquanto que na Grã-Bretanha foram perdidos $68 \%$ (Van Biezen et al., 2012, pp.34-45).

22 Respostas

"frequentemente" e

"ocasionalmente". aporta diversas contribuições. Os autores não apenas confirmam o nível relativamente fraco de investimento dos aderentes como também revelam a estabilidade do grau de participação ${ }^{20}$. Seus resultados indicam uma preferência pelas atividades externas como a panfletagem (praticada por $23 \%$ dos membros em 1991 e $25 \%$ em 2000) e as campanhas eleitorais (tendo passado de $30 \%$ a $35 \%$ no mesmo período) em detrimento das atividades internas (a participação em grupos de estudo fica abaixo de 10\%). Aliás, é notável que a taxa de aderentes que sustenta financeiramente os partidos conhece uma ligeira flutuação, com o recuo da proporção de doadores de $26 \%$ a $24 \%$. Assim, em um caso que podemos sem dúvida qualificar como sendo um dos mais emblemáticos, pela magnitude do declínio do número de filiados ${ }^{21}$, os autores concluem a ausência de indícios comprobatórios da marginalização dos aderentes ou a intensificação de sua participação.

Em contrapartida, Seyd e Whiteley (2004) descobrem resultados divergentes sobre as práticas dos membros dos partidos britânicos. Entre 1990 e 1999, algumas atividades conhecem uma perda de intensidade no investimento dos aderentes, mesmo permanecendo relativamente elevadas: a taxa de respondentes afirmando colar cartazes eleitorais regularmente ${ }^{22}$ passou de $86 \%$ a $79 \%$ enquanto que a taxa daqueles que fazem panfletagem recuou de $77 \%$ a $61 \%$. Outras modalidades caíram a níveis menos expressivos, particularmente a assistência aos meetings e o porta-a-porta que passaram, respectivamente, de $58 \%$ a $48 \%$ e de $55 \%$ a $32 \%$.

Além disso, o estudo do caso do Labour Party fornece um exemplo de que frente às pressões estruturais os dirigentes podem desdobrar um conjunto de incitações de maneira a tornar mais atrativa a participação partidária e a inverter a tendência ao declínio da adesão. Durante a direção de Tony Blair, os efetivos aumentaram cerca de 45\% entre 1992 e 1997, atingindo um nível superior ao que existia a começos dos anos 1980. Assim, o enfoque compreensivo desenvolvido por Seyd e Whiteley (2004) mostra a importância de se insistir sobre a dimensão organizativa ou meso-social (choice-based explanations) a fim de contornar os limites inerentes às explicações macroestruturais. Com efeito, uma das hipóteses que vêm sendo explorada em recentes estudos é que os partidos estão buscando diversificar sua oferta participativa, por exemplo, com a abertura de espaços de participação interna e a instalação de procedimentos consultivos (validação de programas e a seleção de candidatos por eleições primárias $)^{23}$. Além disso, eles estão investindo não apenas em incitações para incorporar uma militância de tipo tradicional como também em novas formas de estreitamento de laços, ainda que flexíveis, entre cidadãos e partidos. Para tanto, empregam-se novas tecnologias comunicacionais da mídia eletrônica (Facebook, e-mails, blogs, Twitter etc.) como canais de informação e de participação política (Norris 2002; Margetts 2006; Greffet 2011; Scarrow 2015) ${ }^{24}$. Assim, se seguimos a célebre representação gráfica proposta por Duverger, os círculos de participação partidária já não são mais concêntricos como ele sugerira, havendo sido multiplicados e assumindo uma geometria aberta em virtude das múltiplas formas e intensidades de envolvimento (multi-speed model, Scarrow 2015) ${ }^{25}$.

IV.3. Práticas, retribuições ao engajamento e identidades partidárias. Uma abordagem interacionista da participação

${ }^{23}$ Seyd e Whiteley (2004) argumentam, ademais, que a integração dos aderentes às deliberações internas também pode trazer repercussões negativas. Seja prolongando o processo decisório, seja pela
Tanto o modelo do cartel quanto as séries quantitativas mostram um alcance limitado para explicar certo número de problemas: por que os partidos de massa são mais afetados pela deserção dos aderentes que os partidos de quadros, enquanto os partidos ecologistas continuam recrutando? Como dar conta das "diferenças substanciais" em nível da participação entre diferentes partidos no interior de um mesmo sistema partidário, cujos membros encontram-se expos- 
veiculação de um partido dividido. Kitschelt (2006) observa que os partidos verdes frequentemente exibem uma imagem caótica decorrente de seus mecanismos participativos.

${ }^{24}$ Esta linha de pesquisa é particularmente propícia à aproximação das tradições acadêmicas e de métodos de análise, como ilustra a obra dirigida por Greffet (2011) e o trabalho de Haegel (2009).

${ }^{25}$ Scarrow (2015, capítulo 6) identifica oito categorias, ou círculos, mais ou menos imbricados: Traditional members, activists, sustainers, light members,

cyber-members, followers, news audience e electors.

${ }^{26}$ Union pour un Mouvement Populaire (UMP), partido de direita francês.
${ }^{27}$ Destarte, as zonas mineiras são caracterizadas por um tipo de adesão hereditária ao comunismo e pela constituição de espaços de socialização congruentes que produzem um tipo de identidade política "fusional". A renovação comunista provoca um ressentimento de que a direção corrói "os fundamentos da cultura partidária" confiscando a identidade política dos antigos militantes (Leclercq 2005, p.148). tos aos mesmos determinantes macroestruturais? Por que os membros dos partidos de esquerda, e mais recentemente dos partidos ecologistas, aparecem como os mais ativos? Os estudos interacionistas, focando os meios partidários, nos apresentam algumas respostas.

A exemplo do que se passa no Labour Party, a UMP ${ }^{26}$ desdobra, a partir de 2004, uma estratégia de ampliação da sua base de aderentes preparando-se para as eleições presidenciais que terão lugar três anos mais tarde. Nos dois casos, os partidos põem em marcha uma série de incitações organizativas com o objetivo de recrutar membros alcançando assim a duplicação de seus efetivos. Em nível interpretativo, enquanto o enfoque compreensivo interessa-se por medir a participação interna e sua evolução (Seyd \& Whiteley 2004), o enfoque interacionista questiona ainda as lógicas organizativas subjacentes à ativação da oferta militante bem como seus efeitos na redefinição do militantismo (Petitfils 2007; Bargel \& Petitfils 2009).

A campanha de recrutamento pilotada pela UMP e, mais além, a própria modernização do partido pela conversão às modernas técnicas de management, são indissociáveis dos jogos de poder internos, do trabalho de legitimação promovido pela nova equipe dirigente e do esforço de alinhamento dos quadros diretivos locais. Petitfils (2007, p.75) mostra que este processo conduz à redefinição mesma do militantismo e das formas de engajamento, o que não é isento de consequências para a desestabilização das estruturas partidárias locais. Aliás, esta dinâmica guarda algumas similaridades com as transformações vividas pelo PS uma década mais cedo. A democratização partidária iniciada pelo Congresso de Rennes (1990) teve profundas repercussões que ultrapassam o efeito da mera diluição dos militantes no corpo de aderentes, como sugere as hipóteses de Katz (1991) e Mair (1994). Os novos espaços abertos à participação, ao valorizarem o debate e a deliberação programática, exigem dos militantes o uso de competências específicas, especialmente escolares, e, paralelamente, desvalorizam as antigas práticas militantes. A intelectualização da participação acarreta a exclusão progressiva dos militantes de origem popular (Lefebvre \& Sawicki 2006). Ora, para um partido de esquerda, a erosão do enlace social não pode ser medida somente pelo recuo do volume global de aderentes, mas ele repousa também sobre a capacidade dos partidos de manter conexões nos meios populares assegurando-se, assim, uma espécie de diversificação sociológica.

Por outro lado, é igualmente possível que as tentativas de renovação patrocinadas pelas direções partidárias possam esbarrar na resistência das elites locais. É o caso da federação comunista do Pas-de-Calais que, frente ao "aggiornamento" impulsionado pela secretaria geral em meados dos anos 1990, entrincheira-se na antiga ortodoxia a fim de preservar a identidade do comunismo local ${ }^{27}$. A onda de desengajamentos que se segue é, em boa medida, explicada pela defecção dos partidários da linha reformadora, insatisfeitos com uma atitude que eles denunciam como anacrônica. Frequentemente portadores de disposições sociais diferenciadas, estes militantes adotam um posicionamento localmente menosprezado e vão sendo distanciados pelos camaradas mais antigos (Leclercq 2005).

Além disso, a observação das práticas militantes permite retraçar o trabalho de construção da identidade partidária. Bargel e Petitfils (2009) demonstram que os efeitos produzidos pela dupla estratégia da UMP, de ampliação da base de aderentes e de valorização do trabalho militante, não são nem automáticos nem homogêneos. Se as campanhas eleitorais são momentos privilegiados para a (re)ativação do vínculo partidário e do sentimento de pertencimento à uma família política, o fato de endossar um papel de militante de terreno tradicionalmente associado aos partidos de esquerda expõe uma série de desajustamentos 
${ }^{28}$ Por exemplo, o acesso a responsabilidades burocráticas, a nominação a candidaturas locais ou a obtenção de um emprego ou uma moradia (Gaxie 1977). Esta afirmação não contradiz os argumentos apresentados na seção 2. Na medida em que um indivíduo investe na organização, suas expectativas, em termos de retribuições, podem evoluir. em relação às propriedades sociais dos atores. Estes desajustamentos traduzem-se por "um sentimento de estranheza inicial" com respeito às tarefas a cumprir, uma sensação de estar realizando "o trabalho ingrato", ou ainda pelo receio de evocar o tema com seus familiares e amigos (Bargel \& Petitfils 2009, p.61). Além disso, as autoras revelam que a divisão do trabalho também está atravessada por lógicas sexuadas. As mulheres investem mais nas tarefas da permanência do partido (secretariado, preparação de materiais, atendimento telefônico), ou seja, em "atividades invisíveis porque não são públicas nem tampouco publicitadas" (Bargel \& Petitfils 2009, p.64).

Por essa razão, os pesquisadores empenham-se em compreender os mecanismos de retribuição do militantismo que permitem manter o engajamento e compensar eventuais desajustamentos. É consenso na ciência política que a adesão ideológica não é suficiente para explicar os esforços consagrados pelos militantes e que, além das vantagens coletivas decorrentes da dedicação à causa, é indispensável que as organizações forneçam também gratificações seletivas (Olson 2011; Gaxie 1977; Panebianco 1982), sejam elas materiais ${ }^{28}$, sejam elas simbólicas:

\begin{abstract}
“A camaradaria, o prazer das 'colagens', das 'vendas' e dos 'porta-a-porta', a solidariedade, a coesão, a comunidade de gostos e de sentimentos, a identificação a um grupo, o júbilo da vitória, os reconfortos mútuos na derrota ou nos revezes individuais, os riscos e as provações enfrentadas em comum, as reuniões onde encontram-se velhos amigos e onde rememoram o passado, as controvérsias apaixonadas, as longas discussões prolongadas num café, o afeto, a cumplicidade, a amizade dos militantes, tudo isso proporciona satisfações que poderíamos julgar prosaicas ou acessórias, mas que constituem porém um potente meio de vinculação ao partido" (Gaxie 1977, p.137).
\end{abstract}

Está claro que as ocasiões que propiciam a obtenção destas satisfações variam entre partidos políticos, seus valores e seu grau de estruturação organizativa. Dito isto, estaríamos equivocados em supor que a construção de identidades, a sociabilidade e o entre-soi militante sejam o apanágio dos aparelhos comunistas e socialistas. Bargel e Petitfils (2009) apontam justamente a festividade que se segue às atividades de terreno, seu caráter transgressivo, como sendo um instrumento indispensável de compensação dos desajustamentos entre disposições sociais e uma identidade militante em um partido de direita. No Green Party, um partido recente e relativamente despojado de recursos, Faucher-King explica a "frenesia militante" observada em um grupo local pela existência "de uma atmosfera convivial, de intensas relações sociais e o sentimento de ser útil" (Faucher-King 1999, p.127). O ritual do chá, a convivência, as festas abertas ao público exterior, entre outros, são tanto elementos que forjam a identidade do grupo local quanto proporcionam satisfações aos militantes, contribuindo assim para a continuidade do seu engajamento.

\section{Incorporando as variáveis sociográficas: do background social dos aderentes à microssociologia do entorno partidário}

A indagação de "quem são os aderentes dos partidos políticos" remonta a uma problemática fundamental da sociologia política, aquela da compreensão dos comportamentos políticos, e que conheceu um desenlace frutuoso na área dos comportamentos eleitorais. Quer se inscrevam na tradição mainstream, quer na francesa, os estudos recentes integram as variáveis sociográficas aos seus respectivos esquemas interpretativos. Nestas duas escolas, alguns trabalhos contentam-se em isolar os determinantes sociais da participação (na linha do trabalho seminal de Lazarsfeld, Berelson \& Gaudet 1968), esboçando uma espécie de background social da adesão. Outros trabalhos incluem também uma preocupação com o pertencimento a distintos grupos sociais, em uma linha próxima àquela aplicada no experimento de Verba e Nie (1972). Não obstante, 
enquanto a Political Science tem apostado na formalização estatística e na modelização, a Sociologie Politique inclina-se à apreensão das lógicas sociais em nível microssocial.

\section{V.1. A origem social como Background}

Desde uma perspectiva compreensiva, as pesquisas por surveys avançaram no delineamento dos contornos sociográficos da adesão partidária (idade, gênero, ocupação, nível de escolaridade, renda, religião, etc.) compondo um quadro bastante preciso da composição social dos filiados aos principais partidos políticos de diversas democracias consolidadas. Explorando estes dados, que alguns autores denominam background characteristics (Gallagher \& Marsh 2004), os especialistas podem determinar o grau de representatividade dos partidos. No nível interno, a comparação dos perfis sociais dos aderentes aos das elites dirigentes (e/ou de eleitos) mostra em que medida a oligarquização dos partidos se acompanha (ou não) de uma diferenciação sociológica. No nível externo, avalia-se o distanciamento (ou a proximidade) das características sociais do partido frente a seus eleitores. Sob este aspecto, as evidências indicam que as organizações funcionam como um primeiro filtro social agindo no recrutamento das elites políticas antes mesmo dos processos de seleção de candidatos.

Ainda que a agregação em nível nacional e a comparação entre distintos sistemas políticos traga um risco de aplanar as especificidades partidárias, selecionamos duas variáveis (gênero e escolaridade) para esboçar algumas tendências atuais (Tabela 1). Uma primeira olhada nos resultados dos trabalhos recentes mostra a predominância masculina no perfil dos aderentes partidários, com a percentagem de homens oscilando desde $62 \%$ nos partidos canadenses até $70 \%$ nos franceses, enquanto que nos partidos britânicos há praticamente uma paridade (em razão da grande proporção de mulheres presentes no Conservative).

As evidências também confirmam a participação partidária como sendo um fenômeno correlato à disposição de recursos sociais. Na tabela 1, esse fator é inferido a partir da variável "escolaridade". Excetuando dinamarqueses e italianos, mais da metade dos filiados possuem um nível de estudos superior ao diploma secundário. Em contrapartida, é mais difícil de estabelecer este tipo de

Tabela 1 - Perfil sociográfico comparado. Variáreis selecionadas

\begin{tabular}{|c|c|c|c|c|}
\hline \multirow[t]{2}{*}{ País } & \multirow[t]{2}{*}{ Partidos } & \multicolumn{2}{|c|}{ Gênero (\%) } & \multirow{2}{*}{$\frac{\text { Escolaridade }}{(\%) \text { superior ao secundário }}$} \\
\hline & & Homens & Mulheres & \\
\hline Bélgica & PS, Ecolo, OpenVLD, CD\&V & 67,2 & 32,8 & 51,8 \\
\hline Canadá & $\begin{array}{l}\text { BQ, CA, LP, NDP, Progressive } \\
\text { Conservative }\end{array}$ & 62,0 & 38,0 & 73,0 \\
\hline Dinamarca & $\begin{array}{l}\text { RGA, SPP, SDP, SLP, CD, ChPP, } \\
\text { LP, CPP, DPP }\end{array}$ & 67,0 & 33,0 & 37,0 \\
\hline França & UMP, PS & 70,0 & 30,0 & 51,0 \\
\hline Grã-Bretanha & Labour, Conservative & 56,0 & 44,0 & n.d. \\
\hline Irlanda & Fine Gael & 69,0 & 31,0 & n.d. \\
\hline Itália & PD, SEL, CD, PSI ${ }^{\mathrm{I}}$ & 68,7 & 31,3 & 41,7 \\
\hline
\end{tabular}

I. Partidos coligados na aliança de centro-esquerda "Italia Bene Comune".

Fonte: O autor, com base em dados disponíveis em: Cross e Young (2004), Gallagher e Marsh (2004), Haegel (2009), Pedersen et al. (2004), Sandri e Seddone (2015), Seyd e Whiteley (1996) e Van Haute et al. (2013). 
${ }^{29}$ Cross e Young (2004) medem o nível de renda; Gallagher e Marsh (2004) estratificação por classes (AB, C1, C2, DE, F); Haegel a categoria sócio-profissional (CSP).

${ }^{30}$ Nesse artigo, o grau de "pilarização" é medido a partir do envolvimento de seus membros em associações auxiliares. Ainda que revelador do grau encapsulação dos filiados em seus espaços sociais de pertencimento, este enfoque distingue-se dos trabalhos franceses por não ter por objetivo retraçar as lógicas sociais da filiação. comparação em torno da ocupação profissional dos aderentes, dada a disparidade entre os indicadores de classificação empregados em cada estudo ${ }^{29}$. Para ilustrar esta dimensão retomamos os resultados de dois casos específicos.

Seyd e Whiteley (1996, p.923) objetivam um distanciamento sociológico "quase perfeito" entre os filiados do Labour e os seus votantes. Enquanto que o eleitorado está majoritariamente constituído de operários (50\%) e de empregados assalariados $(14,5 \%)$, os aderentes do partido se distribuem fundamentalmente entre profissões intermediárias $(50 \%)$. Em contrapartida, a proporção de operários atinge apenas um quarto dos filiados. O estudo de Haegel (2009, p.21) sobre os partidos franceses demonstra que, apesar de uma proximidade entre os partidos dominantes (PS e UMP) em termos de gênero e de nível de escolaridade, outras variáveis sociológicas fixam a linha divisória entre os partidos de direita e esquerda. A UMP está enraizada no setor privado (62\%) e nos meios católicos (84\% de católicos, sendo 35\% praticantes), enquanto o PS recruta no setor público (59\%) e laico (47\% sem religião).

Em termos de exploração analítica, boa parte destes estudos contenta-se em delinear o perfil social dos aderentes (Seyd \& Whiteley 1996; Cross \& Young 2004; Gallagher \& Marsh 2004; Pedersen et al., 2004; Wauters 2010). Recentemente, alguns especialistas têm avançado na utilização de técnicas de regressão logísticas e de análises multivariadas para formalizar modelos. Por exemplo, Van Haute et al. (2013) verifica o grau de "pilarização" dos partidos belgas em certos espaços sociais (pillarization of the grassroots) ${ }^{30}$, enquanto outros trabalhos incluem as características sociográficas ao conjunto de variáveis independentes para explicar as atitudes e comportamentos intrapartidários ${ }^{31}$.

Outra alternativa para o emprego das variáveis sociográficas consiste em buscar uma compreensão social das lógicas de adesão e das modalidades de participação partidária, auscultando aos meios sociais aos quais pertencem os atores bem como as suas redes de interconhecimento. Esta linha marca uma das especificidades dos estudos interacionistas nos quais o principal instrumento é a análise de trajetórias militantes ${ }^{32}$.

\section{V.2. Microssociologia do entorno partidário: carreiras, trajetórias e atores multiposicionados}

${ }^{31}$ Norris (2002), para a intensidade da participação; Van Haute e Carty (2012), para comportamentos desviantes na adesão ideológica; Sandri \& Seddone (2015), para diferenciar as atitudes e os votos de membros e de simpatizantes em eleições primárias. ${ }^{32}$ Encontramos no trabalho de Kitschelt (1990) uma exceção notável, que se inscreve na fronteira entre o enfoque mainstream e a sociologia política (sem, contudo, adotar uma abordagem interacionista).

${ }^{33}$ A noção de "trajetória" remonta à A. Strauss em seu estudo sobre a enfermidade, enquanto a de "carreira" aos trabalhos de E. Hughes sobre as profissões, e de $\mathrm{H}$. Becker sobre os comportamentos desviantes. Segundo Fillieule, estes conceitos podem ser
A busca de um entendimento mais consistente dos mecanismos intrínsecos ao engajamento político conduz a Sociologie Politique a deslocar a problemática de investigação, transpondo-a do "quem são os aderentes (ou militantes)" ao "como" as características sociais dos membros incidem em suas modalidades práticas de participação (ou de distanciamento). As noções de carreira e de trajetória, reapropriadas ao paradigma do interacionismo simbólico e amplamente desenvolvidas pela sociologia dos movimentos sociais, fornecem uma caixa de ferramentas para responder àquela preocupação ${ }^{33}$. Primeiramente, seu interesse repousa na possibilidade de restituir as dinâmicas próprias ao militantismo "não como simples reflexo das constrições estruturais", que, bem entendido, não são ignoradas, e, tão pouco, como um mero "cálculo utilitarista" dos indivíduos (Agrikoliansky 2001, p.30). Sobretudo, colocando em evidência a dimensão sequencial da ação, este instrumento permite levar em consideração o fato de que "a cada etapa da biografia, as atitudes e comportamentos são determinados pelas atitudes e comportamentos passados que condicionam, a sua vez, o campo das possibilidades vindouras, re-situando assim os períodos de engajamento no conjunto do ciclo de vida" (Fillieule 2001, p.201). O militantismo é então apreendido em sua dimensão processual composta por etapas sucessivas: a adesão (predisposições, recrutamento, passagem ao ato), sua manutenção (formas e intensidades do engajamento que se modificam com o tempo) e a defecção (retirada para a vida privada, reconversão em outro partido ou em um movimento social) ${ }^{34}$. 
empregados indiferentemente dado que provêm "de uma mesma tradição e partilham certo número de propriedades, isto é, igual atenção aos processos e à dialética permanente entre história individual e instituição, e mais amplamente, os contextos" (Fillieule 2001, p.200).

${ }^{34}$ Metodologicamente, as bases de dados são confeccionadas a partir de surveys, de entrevistas biográficas ou da reconstituição prosopográfica.

${ }^{35}$ Para um esforço de objetivação interacionista e de compatibilização da abordagem "por carreiras" à sociologia bourdieasiana, ver Darmon (2008).

${ }^{36}$ Assim sendo, "a noção de carreira não conduz, como deixaria pensar uma leitura demasiado rápida do paradigma interacionista, a ignorar as variáveis estruturais, mas sim a contextualizar seus efeitos práticos quando das diferentes sequências de ação" (Agrikoliansky 2001, p.31). ${ }^{37}$ Para os objetivos da presente síntese, nos deteremos somente sobre 0 exemplo de reconversões sem ruptura (esta não é a única bifurcação possível), que parece ter sido seguida por uma quantidade significativa de militantes, como indica a taxa de $94 \%$ de militantes multiposicionados em sindicatos e associações dentre os delegados do XV Congresso da LCR em 2003 (Johsua 2007, pp.43-44).

\footnotetext{
${ }^{38}$ Inclusive em termos de tensões internas que são decorrentes.
}

De acordo com Sawicki (1988), o estudo das trajetórias sociais e políticas esclarece a maneira como os atores adquirem recursos, savoir-faire e interesses específicos que não se reduzem à sua posição na hierarquia social (o background sociológico). Para o politólogo, é compreendendo os mecanismos de ativação de propriedades sociais, através dos múltiplos sítios nos quais se inscrevem os atores, que a variável "origem social" adquire todo seu sentido. Isto porque as posições assumidas pelos atores, como a decisão de aderir a um partido, não se restringem à expressão mecânica de suas disposições de classe: "uma frase tão frequentemente pronunciada como 'o PS é um partido de docentes' não tem muito significado em si mesma, primeiro se não é precisado de quais categorias de professores estamos tratando e, sobretudo, qual foi sua via de acesso ao partido: militantismo laico, sindical, associativo, católico, mandato eletivo em zona rural?" (Sawicki 1988, p.14). Portanto, o recurso à noção de trajetórias possibilita-nos exceder o delineamento de perfis sociográficos dos militantes avançando na compreensão das lógicas sociais do compromisso e, ao mesmo tempo, evitando as derivas deterministas da sociologia disposicional ${ }^{35}$.

Desde então, um dos principais desafios interpretativos que se impõe aos investigadores é o de articular o estudo das lógicas individuais (nível micro-sociológico) à dinâmica organizativa (nível meso-social) e, mais amplamente, às transformações estruturais ${ }^{36}$. Encontramos no estudo de Johsua (2007) um exemplo profícuo de aplicação deste marco analítico para explicar a metamorfose vivenciada pela Liga Comunista Revolucionaria (LCR). Acometida a fins dos anos 1980 por uma conjuntura cada vez menos receptiva as suas proposições, a LCR conhece um declínio acelerado do número de membros. Muitos de seus quadros militantes orientam-se então a engajamentos concomitantes nos meios sindical e associativo ${ }^{37}$. Estes espaços oferecem-lhes "um repertório de objetivos e de táticas" pelos quais eles conseguem "manter sua mobilização e conservar sua identidade coletiva através do tempo" (Johsua 2007, pp.40-41). Paralelamente, levando os militantes da LCR a interagirem com outros movimentos sociais e a ampliarem seu repertório de ação, por um lado, e oferecendo outro espaço de socialização política, por outro, estas experiências exercem sobre os atores um efeito de aculturação que, associado à decomposição de algumas de suas referências ideológicas, contribui à reelaboração da identidade coletiva da LCR. Neste novo contexto, o partido inicia, nos anos 1990, uma abertura aos movimentos sociais que resultará, no horizonte de 2002, na duplicação de seus efetivos, restabelecendo uma afluência próxima daquela de meados dos anos 1970. Johsua consegue assim, através da análise de trajetórias individuais, dar conta das transformações operadas tanto no nível das modalidades de engajamento, quanto no nível organizativo e, portanto, a explicar como o partido logra (re)produzir-se e recrutar novos membros.

Como ilustra o caso da LCR, a abordagem pelas trajetórias militantes realça a importância de se considerar as circulações entre espaços sociais a fim de compreender tanto as lógicas do militantismo quanto a moldagem organizativa dos partidos. Sob este ângulo, a investigação de Combes (2004) sobre o PRD mexicano revelou um modo de recrutamento fundamentalmente apoiado em organizações não partidárias (associações, movimentos sociais, sindicatos ou ONGs), atraindo secundariamente antigos militantes de outros partidos políticos. O savoir-faire acumulado nas lutas sociais que é trazido pelos líderes multiposicionados é crucial para o trabalho de organização das seções locais e de enquadramento dos militantes ${ }^{38}$. Por um lado, o repertório de ação do partido (com uma valorização das mobilizações de tipo não institucional) e, mais além, o próprio ethos militante são profundamente marcados por esta imbricação. Por outro, a participação político-partidária pode assumir uma forma intermitente (Combes 2006). Outros trabalhos confirmaram estas constatações, inclusive em 
partidos de direita. Na UDF (direita moderada na França), onde a experiência nos círculos católicos é um traço marcante do perfil dos ativistas, "a multiadesão é moeda corrente, e é mesmo constitutiva do ethos militante" (Fretel 2011, p.337). Fretel mostra também que, neste partido, dirigentes e eleitos desenvolveram vastas redes locais, frequentemente no meio associativo, que constituem recursos reputacionais mobilizáveis tanto durante as campanhas eleitorais como nas lutas no seio do partido. Ao mesmo tempo, estas associações propiciam a criação de vínculos sociais e políticos com cidadãos que, de outra maneira, seriam reticentes em filiar-se a um partido (Fretel 2004). No Forza Italia os jovens militantes estão implicados em "estruturas sociais conexas ou 'satelitais' como os círculos, notabilidades, associações culturais (especialmente católicas) ou profissionais" (Dechezelles 2009, p.44). Nestas esferas sociais, eles obtêm recursos para levar a cabo suas atividades políticas (como a realização de conferências, por exemplo) e o sustém necessário para desenvolver suas próprias carreiras.

Desse modo, estes estudos indicam que o trabalho de construção de enlaces políticos entre o Estado e os cidadãos não está necessariamente circunscrito ao enrolamento de aderentes e a sua participação na vida interna dos partidos. Ao contrário, e apesar da diferenciação funcional entre diferentes tipos de organizações, pode haver um continuum na participação político-partidária entre práticas convencionais e não-convencionais. Da mesma maneira que produz efeitos sobre o militantismo e as organizações partidárias, o multiposicionamento dos atores pode contribuir à politização (quiçá a sua intensificação) de organizações sociais ou de indivíduos mobilizados em torno a uma problemática, mas que não consideram orientar-se a um engajamento partidário (Fretel 2004; Johsua 2007). Em nossos próprios trabalhos também constatamos esta dinâmica no caso da imbricação entre pequenos partidos de esquerda e associações de bairro em conflitos de oposição a projetos de intervenção urbana na cidade de Buenos Aires. Através de seus militantes, os partidos contribuem para entreter a mobilização sem, contudo, lograrem reconverter estas redes em suas campanhas eleitorais (Nique Franz 2014).

Enfim, um último ponto que merece ser destacado no estudo das trajetórias concerne a possibilidade de que a experiência militante produza sobre os indivíduos efeitos duradouros que continuam a agir mesmo depois do desengajamento. Leclerq descobre, entre os militantes que deixam o PCF, uma espécie de "fidelidade na ruptura". Desligados das atividades na federação local e abstendo-se de renovar suas cartas de adesão, estes ex-militantes

“continuam a ler diariamente L'Humanité e a caucionar as iniciativas da direção nacional, indo por vezes até o ponto de enviar sua cotização diretamente à sede parisiense. Nas novas gerações de militantes, em ascensão social, mais escolarizadas e tendo circulado em outros espaços de sociabilidade, pode haver uma transferência de interesse em direção a outras formas de militantismo como o associativo. Nestes casos, o desengajamento não resulta nem de uma 'decepção política' nem tampouco da 'descrença' no partido” (Leclerq 2005, p.153).

Vê-se claramente que, seja no recolhimento à esfera privada ou no deslocamento do seu ativismo, os atores podem manter sua fidelidade a uma identidade política de maneira que o desengajamento não implica o abandono dos princípios de divisão do mundo social incorporados no partido (no sentido de Bourdieu 1981). Como ilustra o estudo de Gouard (2013), esta identidade é suscetível de ser reativada, reformulada e, inclusive, traduzida em um sustento eleitoral. Tudo depende do trabalho de reativação e atualização de disposições que se operam no âmago das redes nas quais circulam os atores (sejam elas sindical, religiosa, associativa ou inclusive espaços de sociabilidade informais). Em definitiva, parece que "a identidade política pode perdurar independentemente de uma filiação partidária” (Gouard 2013, p.215), o que 
reforça o argumento de que o political linkage não pode reduzir-se somente ao indicador fornecido pela adesão a um partido político.

\section{Conclusões}

Há um consenso de que as transformações ocorridas nas sociedades ocidentais impactaram o modo de organização dos partidos políticos e as formas de participação político-partidária da cidadania. Ambas as escolas analisadas neste artigo buscaram compreender este processo, desenvolvendo análises empíricas e apoiando-se em dados robustos, quantitativos e qualitativos, que fornecem um quadro bastante preciso do fenômeno. É certo que os especialistas são menos concordantes no momento de teorizar esta nova configuração e diversas críticas foram levantadas de encontro ao modelo do partido cartel. Apesar disto, os resultados obtidos nas últimas décadas constituem um avanço considerável, ainda mais quando comparados à escassez de material empírico de que dispunha Duverger em sua época.

A tradição da Policial Science delineou a curva da adesão partidária em longa duração, objetivando seu declínio neste último quarto de século. Seus estudos comparativos demonstraram a importância das incitações ideológicas e programáticas no recrutamento dos filiados, revelaram seu perfil sociográfico e verificaram a intensidade da participação em distintos tipos de atividades, destacando, no caso dos ativistas, uma inclinação à priorização de tarefas externas (excetuando-se o caso dinamarquês). A seu turno, a Sociologie Politique trouxe à luz as práticas e identidades militantes, suas transformações e os conflitos internos que são decorrentes. Empregando a análise de trajetórias, os trabalhos puseram em evidência a circulação dos atores entre espaços sociais e as múltiplas formas de construção de conexões entre os partidos e a sociedade. Para encerrar esse balanço, incumbe que teçamos algumas críticas para apontar os limites do alcance de ambas as perspectivas.

O primeiro grande obstáculo à realização de pesquisas por surveys de grande envergadura repousa nos custos financeiros adjacentes (envio e reenvio de um numero consequente de questionários, codificação e construção da base de dados, tratamento estatístico). Sem o apoio de agências de fomento, este tipo de projeto é praticamente inviável.

De um ponto de vista epistemológico a principal crítica endereçada aos trabalhos comparativos e à prova estatística é de que esta abordagem enseja um risco de produzir uma visão demasiado esquemática e homogeneizante da participação política e dos mecanismos de mobilização partidária. Neste sentido, a comparação dos níveis de participação entre diferentes partidos suscita importantes questões teóricas, discutidas nos trabalhos clássicos de Duverger (1976) e de Lagroye et.al. (1976), mas eludidas na maioria dos estudos da Political Science. Posto que o sentido que é atribuído à participação dos aderentes difere em cada tipo de partido (quer ele seja de massas, seja de quadros, de esquerda ou de direita) e, da mesma maneira, é suscetível de variar em função das diferenças históricas de cada país, a agregação de dados resulta uma operação, em certo sentido, arbitrária. Ademais, tampouco estão explicitados os indicadores determinantes para a qualificação da intensidade da participação partidária. Seria a taxa daqueles que participam dos grupos de estudos fora dos períodos eleitorais ou mais bem daqueles que colam cartazes durante as campanhas? Inclusive, podemos evocar um problema de calibragem: como demarcar a linha a partir da qual classificar como "fraco", "médio" ou "alto" o nível de participação em uma associação voluntária? ${ }^{39}$ Quando certo número de atividades mobiliza mais da metade dos aderentes? Ou quando atingem $60 \%$ ou $80 \%$ ? Mas ao mesmo tempo, porque razão não o estabelecer em $40 \%$ ? Finalmente, não podemos negligenciar a ausência de uma base de referência a partir da qual

${ }^{39}$ Uma discussão similar é desenvolvida por Duverger (1976, pp.117-118) e por Lagroye et al. (1976, p.160). 
Por sua vez, Scarrow sublinha que, "building an historically informed baseline to study party membership decline is not just a matter of having exact membership numbers. Equally important is the recognition that parties reasons for enlisting members have varied across parties, and have changed over time within single parties" (Scarrow 2015, p.2).

40 Para uma análise dos problemas subjacentes à estimação do número de aderentes e à construção de bases de dados, ver Scarrow (2000; 2015).

${ }^{41}$ Neste sentido, o trabalho de Fretel (2011) lembra que o modelo do partido de massas não constitui um modo de organização ótimo para todo tipo de partido. Pequenos partidos podem forjar um ethos militante e resolver suas necessidades organizativas, ainda que não recorram ao recrutamento massivo e ao trabalho intenso dos ativistas.

${ }^{42}$ Boa parte dos autores se abstêm, contudo, de discutir os limites destes, e isto apesar de que suas conclusões apresentem frequentemente considerações de ordem normativa a propósito da deterioração da função de enlace social atribuída aos partidos, como Bille (1994) ou Heidar \& Saglie (2003, p.764) "only a minority of party members was active in a way that could be considered democratically significant". comparar a evolução da participação em média e longa duração. Pois, se é possível estimar a taxa de adesão aos partidos desde o final do século $\mathrm{XIX}^{40}$, não dispomos de dados quantitativos suficientes para apreciar o nível de participação dos aderentes nem sequer durante a "idade de ouro" dos partidos de massa ${ }^{41}$.

Também podemos sublinhar as dificuldades advindas dos modos de construção de dados e de sua comparabilidade. Observamos variações no que tange os tipos de atividades selecionadas em cada pesquisa (a questão da contribuição financeira dos aderentes não aparece em todos os papers; em termos de participação, podem ser tomadas em conta tanto a assistência de meetings públicos durante as campanhas eleitorais, quanto a presença em reuniões locais). As unidades de medida tampouco são idênticas. Seyd e Whiteley (2004) utilizam a intensidade das práticas (frequentemente, ocasionalmente, etc.) enquanto Heidar e Saglie (2003) empregam a proporção de membros que participaram ao menos uma vez às atividades selecionadas. Os estudos são também díspares no tocante à escolha do período examinado. Na maioria das sondagens, os aderentes são consultados sobre suas práticas relativas ao ano precedente à pesquisa, no trabalho de Pedersen (2006) são considerados os cinco anos anteriores. Além do mais, a utilização de dados agregados, calculando as taxas médias de participação dos partidos nacionais, é sensível ao universo de partidos tomados em consideração: eles são nove no estudo de Pedersen, sete no de Heidar e Saglie, quatro no de Van Haute (2012) e três no de Seyd e Whiteley. Tudo isto, bem entendido, não desestima em absoluto a qualidade das demonstrações providas nestes trabalhos. Mas as considerações que acabamos de expor convidam a não superestimar o potencial explicativo dos estudos quantitativos $^{42}$.

Por sua vez, o enfoque interacionista, apoiando-se em métodos sócioetnográficos, aduz outros desafios ao investigador. Por um lado, o acesso ao "campo", ou seja, a inserção no grupo a ser estudado (obtenção de arquivos, entrevistas com lideranças e eleitos) pode revelar-se uma tarefa laboriosa. Os partidos políticos, como qualquer empresa, são relutantes em abrir sua "caixa preta" aos observadores externos. Acrescente-se a isto o fato de que a própria proposta etnográfica exige um trabalho de seguimento sistemático, de convivência com os militantes, ou mesmo de observação participante. Portanto, incide, neste tipo de pesquisa, um "custo" em termos do tempo necessário à coleta de dados. Além disso, é imprescindível que o investigador esteja atento tanto às distorções geradas por sua presença na organização como à objetivação de sua posição e do tipo de vínculo estabelecido com seu objeto, a fim de controlar os efeitos da subjetividade.

Por outro lado, o método adotado pela sociologia política francesa impõe ao pesquisador incontestáveis limites no tocante à abrangência dos resultados obtidos. As conclusões atinentes a uma federação podem ser estendidas às demais? Em que medida os fenômenos observados podem ser aplicados a outras ocorrências? Podem-se desprender tendências gerais para além das especificidades dos casos estudados? Dificilmente, há de reconhecer, os trabalhos monográficos derivam em extrapolações universalizantes ou em modelos tipológicos de partidos, das redes nas quais se inserem, ou das formas de militantismo que os animam. Alcançar um grau de generalização consiste, pois, em um dos principais desafios desta tradição. Este problema reenvia, claro está, às controvérsias epistemológicas inerentes aos distintos paradigmas das ciências sociais.

Posto que aprofundar esse debate e tentar desenlaçar estes imbróglios ultrapassa os objetivos fixados no presente artigo, contentamo-nos apenas a tecer dois comentários. Primeiro, pese os obstáculos existentes a alcançar certa generalização, e uma ausência de ambição de modelização, os trabalhos em 
sociologia política são capazes de integrar conhecimentos prévios, de discutir aportes teóricos, de demonstrar regularidades empíricas e de elaborar conceitos. Em outras palavras, eles são, indubitavelmente, promotores de cumulatividade científica (Favre 2012). Segundo, como buscamos ilustrar ao longo de nossa análise, os estudos quantitativos não são menos acometidos por este tipo de limites, posto que seus resultados são suscetíveis de apresentar variações significativas, seja no âmago de um mesmo país, seja na comparação entre diferentes sistemas partidários.

Em definitivo, tomados em conjunto, estes estudos permitem desprender algumas tendências gerais da participação político-partidária na contemporaneidade. Em sua maioria, os autores consentem que partidos não foram completamente desertados. Os indícios tão pouco sustentam que estejamos encaminhando-nos para uma configuração de partidos sem partidários, ainda que a demanda de trabalho militante tenha sido reduzida. As organizações têm-se mostrado reativas, podendo, com êxitos variáveis, promover incitações que encorajem a filiação e a participação. Assim, os aderentes e militantes continuam preenchendo certo número de funções, embora a preservação destes vínculos suscite sérios dilemas às elites partidárias. Neste sentido, as pesquisas convergem em apontar uma propensão à diversificação das formas de envolvimento. Os aderentes tendem a ganhar mais poder de decisão e de consulta em eleições primárias e na validação do programa, ainda que os militantes possam vir a ser marginalizados. Paralelamente, as tecnologias eletrônicas de comunicação, principalmente a internet, abrem espaço ao ciber-militantismo, embora produzindo vínculos atomizados e individualizados. Em particular, a Sociologie Politique, ao insistir na dimensão não-convencional da participação, revela formas intermitentes e plurais de engajamento, sem dúvida de amplitude dessemelhante, nas quais o pertencimento a um partido pode ser oscilante ou concomitante com o envolvimento em movimentos sociais. Aqui consiste, em nosso entendimento, um aporte relevante para a compreensão das transformações ocorridas no enraizamento social dos partidos.

Avançando na proposição de uma agenda de pesquisas, esta revisão da literatura autoriza-nos a sugerir três eixos com grande potencial para serem explorados. Primeiro, aprofundar o estudo destas novas formas de participação. Segundo, analisar a circulação de militantes entre espaços sociais indagando as condições de possibilidade (e as dificuldades) destas reconversões. Terceiro, re-interrogar o militantismo "tradicional" para apreender tanto suas transformações como os desafios que se apresentam à sua profissionalização. A combinação de métodos de análise, quantitativo e qualitativo, monográfico e comparativo, é sem dúvida profícua desde que tomadas as precauções necessárias. Em todos os casos, parece urgente romper com a compartimentalização que vem dificultado o diálogo entre as perspectivas desenvolvidas pela Political Science e pela Sociologie Politique.

Walter F. Nique Franz (wniquefranz@ gmail.com) é Doutorando em Ciência Política , bolsista do programa de doutorado pleno no exterior (CAPES). Vínculo Institucional: Centre Européen de Sociologie et de Science Politique (CESSP), Université Paris 1 Panthéon-Sorbonne, Paris, França.

\section{Referências}

Agrikoliansky, E., 2001. Carrières militantes, et vocation à la morale: les militants de la Ligue des droits de l'homme dans les années 1980. Revue Française de Science Politique, 51(1-2), pp.27-46. DOI: 10.3406/rfsp.2001.403606

Aucante, Y. \& Dézé, A., ed., 2008. Les systèmes de partis dans les démocraties occidentales: le modèle du parti-cartel en question. Paris: Presses de Sciences Po.

Barboni, T., 2010. Les changements d'une organisation. Le parti socialiste, entre configuration partisane et cartelisation (1971-2007). Tese de Doutorado. Paris: Université Paris I. 
Bargel, L. \& Petitfils, A.S., 2009. “Militants et populaires!" une organisation de jeunesse sarkozyste en campagne. L'activation périodique d'une offre organisationnelle de militantisme et ses appropriations pratiques et symboliques. Revue Française de Science Politique, 59(1), pp.51-75. DOI : 10.3917/rfsp.591.0051

Bille, L., 1994. Denmark: The Decline of Membership Party? In R. Katz \& P. Mair, eds. How Parties Organize. Change and Adaptation in Party Organizations in Western Democracies. London: Sage Publications.

2001. Democratizing a Democratic Procedure: Myth or Reality? Candidate Selection in Western European Parties, 1960-1990. Party Politics, 7(3), pp.363-380. DOI: 10.1177/1354068801007003006

Bourdieu, P., 1981. La représentation politique. Actes de la Recherche en Sciences Sociales, 36-37, pp.3-24. DOI: 10.3406/arss.1981.2105 2000. Propos sur le champ politique. Lyon: PUL

Combes, H., 2004. De la politique contestataire à la fabrique partisane. Le cas du Parti de la révolution démocratique au Mexique (1989-2000). Tese de Doutorado. Paris: IHEAL/Université Paris III.

, 2006. Des militants par intermittence ? Le Parti de la révolution démocratique au Mexique (1989-2000). Critique Internationale, 30(1), pp. 145-160. DOI: 10.3917/crii.030.0145

Darmon, M., 2008. La notion de carrière: un instrument interactionniste d'objectivation. Politix, 82(2), pp.149-167. DOI: 10.3917/pox.082.0149

Dechezelles, S., 2009. Des vocations intéressées? Les récits d'engagement des jeunes de Forza Italia à l'aune du modèle rétributif du militantisme. Revue Française de Science Politique, 59(1), pp.29-50. DOI: 10.3917/rfsp.591.0029

Delwit, P., 2011. Still in Decline? Party Membership in Europe. In E. Van Haute, ed. Party Membership in Europe: Exploration in to the Anthills of Party Politics. Bruxelles: Editions de l'ULB.

Detterbeck, K., 2008. Le cartel des partis et les partis cartellisés en Allemagne. In Y. Aucante \& A. Dézé, eds. Les systèmes de partis dans les démocraties occidentales: Le modèle du parti-cartel en question. Paris: Presses de Sciences Po.

Downs, A., 1957. An Economic Theory of Political Action in Democracy. The Journal of Political Economy, 65(2), pp.135-150. DOI: 10.1086/257897

Duverger, M., 1967. Les partis politiques. 6a ed. Paris: Armand Colin.

Faucher-King, F., 1999. Les habits verts de la politique. Paris: Presses de Sciences Po.

Favre, P., 2012. Politix, 1988-2012: changement de génération, basculement de paradigmes. Politix, 4(100), pp.41-62. DOI: 10.3917/pox.100.0041

Favre, P. \& Fillieule, O., 1994. La manifestation comme indicateur de l'engagement politique. In P. Perrineau, ed. L'engagement politique, déclin ou mutation? Paris: Presses de Sciences Po.

Fillieule, O., ed. 2005. Le désengagement militant. Paris: Belin. ,2001. Propositions pour une analyse processuelle de l'engagement individuel. Revue Française De Science Politique, 51(1-2), pp.199-217. DOI: 10.3917/rfsp.511.0199

Fretel, J., 2004. Le parti comme fabrique de notables. Réflexions sur les pratiques notabiliaires des élus de l'UDF. Politix, 17(65), pp.45-72. DOI: 10.3406/polix.2004.1609

,2011. Qual sociologia para o estudo dos partidos políticos conservadores? Revista Brasileira de Ciência Política, 5, pp.321-349. DOI: 10.1590/s0103-33522011000100012

Gallagher, M. \& Marsh, M., 2004. Party Membership in Ireland: The Members of Fine Gael. Party Politics, 10(4), pp.407-425. DOI: $10.1177 / 1354068804043906$

Gaxie, D., 1977. Économie des partis et rétributions du militantisme. Revue Française De Science Politique, 27(1), pp.123-154. DOI: 10.3406/rfsp.1977.393715

, 1993. Le vote désinvesti. Quelques éléments d'analyse des rapports au vote. Politix, 6(22), pp.138-164. DOI: 10.3406/polix.1993.2049

Gouard, D., 2013. Les recompositions contemporaines de l'affiliation au communisme en banlieue parisienne. In E. Bellanger \& J. Mischi, ed., Les territoires du communisme. Elus locaux, politiques publiques et sociabilités militantes. Paris: Armand Colin

Greffet, F., ed., 2011. Continuerlalutte.com, les partis politiques sur le web. Paris: Presses de Sciences Po

Haegel F., 2009. La mobilisation partisane de droite. Les logiques organisationnelles et sociales d'adhésion à l'UMP. Revue Française de Science Politique, 59(1), pp.7-27. DOI: 10.3917/rfsp.591.0007

Heidar, K. \& Saglie, J., 2003. A Decline of Linkage? Intra-Party Participation in Norway, 1991-2000. European Journal of Political Research, 42, pp.761-786. DOI: 10.1111/1475-6765.00103

Inglehart, R., 1977. The Silent Revolution: Changing Values and Political Styles Among Western Publics. Princeton: Princeton University Press.

Ion, J., 1997. La fin des militants? Paris: Les Editions de l'Atelier.

Johsua, F., 2007. Les conditions de (re)production de la LCR. L'approche par les trajectoires militantes. In F. Haegel, ed., Partis politiques et système partisan en France. Paris: Presses de Sciences Po.

Katz, R., 1990. Party as Linkage: A Vestigial Function? European Journal of Political Research, 18(1), pp.143-161. DOI: 10.1111/j.1475-6765.1990.tb00225.x

Katz, R. \& Mair, P., eds., 1992. Party Organizations: A Data Handbook on Party Organizations in Western Democracies (1960-1990). London: Sage Publications. 1994. How Parties Organize: Change and Adaptation in Party Organizations in Western Democracies. London: Sage Publications. 
1995. Changing Models of Party Organization and Party Democracy: The Emergence of the Cartel Party. Party Politics, 1(1), pp.5-28. DOI: 10.1177/1354068895001001001

Kirchheimer, O., 1966. The Transformation of West European Party Systems. In J. LaPalombara \& M. Weiner, eds. Political Parties and Political Development. Princeton: Princeton University Press.

Kitschelt, H., 1990. New Social Movements and Party Organization. In R.J. Dalton \& M. Kuechler, eds. Challenging Political Order. Cambridge, UK: Polity Press.

, 2000. Citizens, Politicians, and Party Cartellization: Political Representation and State Failure in Post-Industrial Democracies. European Journal of Political Research, 37(2), pp.149-179. DOI: 10.1111/1475-6765.00508

2006. Movement parties. In R. Katz \& W. Crotty, eds. Handbook of Party Politics. London: Sage Publications.

Kölln, A.K., 2014. Party Membership in Europe: Testing Party-Level Explanations of Decline. Party Politics, 22(4), pp.465-477. DOI: $10.1177 / 1354068814550432$

Koole, R., 1996, Cadre, Catch-all or Cartel? A Comment on the Notion of the Cartel Party. Party Politics, 2(4), pp.507-523. DOI: $10.1177 / 1354068896002004004$

Lagroye, J.; Lord, G.; Mounier-Chazel, L. \& Palard, J., 1976. Les militants politiques dans trois partis français. Parti Communiste, Pati Socialiste, Union des Démocrates pour la République. Paris: Pedone.

Lawson, K., ed. 1980. Political Parties and Linkage. New Haven: Yale University Press. , 1988. When Linkage Fails. In K. Lawson \& P.H. Merkl. When Parties Fail. Emerging Alternative Organizations. Princeton: Princeton University Press.

Lazarsfeld, P.F.; Berelson, B. \& Gaudet, H., 1968. The People's Choice: How the Voter Makes Up His Mind in a Presidential Campaign. $3^{\text {a }}$ ed. New York: Columbia University Press.

Leclercq, C., 2005. Raisons de sortir. Le désengagement des militants du PCF. In O. Fillieule, ed. Le désengagement militant. Paris: Belin.

Lefebvre, R. \& Sawicki, F., 2006. La société des socialistes. Le PS aujourd'hui. Broissieux: Editions du Croquant

Mair, P., 1994. Party Organizations: From Civil Society to the State? In R. Katz \& P. Mair, eds. How Parties Organize. Change and Adaptation in Party Organizations in Western Democracies. London: Sage Publications.

Margetts, H., 2006. Cyber Parties. In R. Katz \& W. Crotty, eds. Handbook of Party Politics. London: Sage Publications.

Mathieu, L., 2012. L'espace des Mouvements Sociaux. Broissieux: Editions du Croquant.

Matonti, F., ed., 2005. La démobilisation politique. Paris: La Dispute.

Mischi, J., 2013. Vers un parti d'élus. La réorganisation locale du PCF dans les années 1980 et 1990. In E. Bellanger \& J. Mischi, eds. Les territoires du communisme. Elus locaux, politiques publiques et sociabilités militantes. Paris: Armand Colin.

Nique Franz, W.F., 2014. En défense de l'espace public. L'Articulation entre Proyecto Sur et des mouvements contestataires dans la zone centrale de la ville de Buenos Aires. In Colloque International La survie et la domination du péronisme en Argentine: une énigme sociologique? Paris.

Norris, P., 2002. Democratic Phoenix. Reinventing Political Activism. Cambridge, UK: Cambridge University Press.

Olson, M., 2011. Logique de l'action collective. Bruxelles: Editions de l'ULB.

Panebianco, A., 1982. Modelos de partidos. Organización y poder en los partidos políticos. Madrid: Alianza editorial.

Pedersen, K., 2006. Mirror, Mirror on the Wall, Who's the Greenest of Them All? The Greenness of Danish Party Membership Linkage. Working Paper, Institut for Statskundskab, pp.1-29.

Pedersen, K. et al., 2004. Sleeping or Active Partners? Danish Party Members at the Turn of the Millennium. Party Politics, 10(4), pp.367-383. DOI: 10.1177/1354068804043904

Perrineau, P., ed., 1994. L'engagement politique, déclin ou mutation? Paris: Presses de Sciences Po.

Petitfils, A.S., 2007. L'institution partisane à l'épreuve du management. Rhétorique et pratiques managériales dans le recrutement des «nouveaux adhérents » au sein de l'Union pour un Mouvement Populaire (UMP). Politix, 79(3), pp.53-76. DOI: 10.3917/pox.079.0053

Popkin, S.L., 1994. The Reasoning Voter. Communication and Persuasion in Presidential Campaigns. Chicago: University of Chicago Press.

Sandri, G. \& Seddone, A., 2015. Sense or Sensibility? Political Attitudes and Voting Behavior of Party Members, Voters, and Supporters of the Italian Centre-Left. Italian Political Science Review, 45(1), pp.25-51. DOI: 10.1017/ipo.2015.2

Sawicki, F., 1988. Questions de recherche: pour une analyse locale des partis politiques. Politix, 1(2), pp.13-28. DOI: 10.3406/polix.1988.1335

2001. Les partis politiques comme entreprises culturelles. In D. Cefaï, ed. Les cultures politiques. Paris: PUF.

, 2011. Partis politiques et mouvements sociaux: des interdépendances aux interactions en retour. In S. Luck \& S. Dechezelles, eds. Voix de la rue ou voie des urnes? Mouvements sociaux et partis politiques. Rennes: PUR.

Scarrow, S.E., 2000. Parties without Members? Party Organization in a Changing Electoral Environment. In R. Dalton \& M. Wattenberg, eds. Parties without Partisans: political Change in Advanced Industrial Democracies. New York: Oxford University Press.

2015. Beyond Party Members. Changing Approaches to Partisan Mobilization. New York: Oxford University Press.

Seyd, P. \& Whiteley P., 1996. L'évolution récente des adhérents du Parti conservateur et du Parti travailliste en Grande-Bretagne. Revue Française de Science Politique, 46(6), pp.914-935. DOI: 10.3406/rfsp.1996.395114 , 2004. British Party Members. An Overview. Party Politics, 10(4), pp.355-366. 
Van Biezen, I.; Mair, P. \& Poguntke, T., 2012. Going, Going, Gone? The Decline of Party Membership in Contemporary Europe. European Journal of Political Research, 51(1), pp. 24-56. DOI: 10.1111/j.1475-6765.2011.01995.x

Van Haute, E., 2012. Crowds of Passive Followers? The Study of Party Membership and Activism in Belgium. In MAPP Workshop. Bruxelles.

Van Haute, E. \& Carty, R.K., 2012. Ideological Misfits: A Distinctive Class of Party Members. Party Politics, 18(6), pp. 885-895. DOI: $10.1177 / 1354068810395058$

Van Haute, E. et al., 2013. Party Members in a Pillarised Partitocracy. An Empirical Overview of Party Membership Figures and Profiles in Belgium. Acta Politica, 48, pp.68-91. DOI: 10.1057/ap.2012.25

Verba, S. \& Nie, N., 1972. Participation in America. New York: Harper \& Row.

Wauters, B., 2010. Explaining Participation in Intra-Party Elections. Evidence from Belgian Political Parties. Party Politics, 16(2), pp.237-259. DOI: 10.1177/1354068809339541

Young, L. \& Cross, W., 2002. Incentives to Membership in Canadian Political Parties. Political Research Quarterly, 55(3), pp.547-570. DOI: 10.1177/106591290205500303

Ysmal, C., 1994. Transformation du militantisme et déclin des partis. In P. Perrineau, ed. L'engagement politique, déclin ou mutation? Paris: Presses de Sciences Po.

\section{Artigos de jornais}

Le Parti socialiste vise les 500000 adhérents d'ici à 2017. 2014. Le Monde, 13 Dec.

\section{Outras fontes}

CNCCFP, 2012. Publication générale des comptes des partis et groupements politiques au titre de l'exercice 2011. Journal Officiel de la République Française, 301, 27 Dec.

Alemanha. Deutscher Bundestag, 1994. Act on Political Parties. Disponível em: https://www.bundestag.de/blob/189734/2f4532b00e4071444a62f360416cac77/politicalparties-data.pdf. Acesso em: 30 out. 2016.

2007. Fixation du montant des fonds publics pour l'année 2007. Disponível em: http://www.bundestag.de/blob/190310/a077bc24ff0a5611aa93253f8e2acf48/fixation-data.pdf. Acesso em: 30 out. 2016. 
Party membership and militants: Political participation in the era of the Cartel Party.

\section{Abstract}

This work analyzes the état de l'art of literature about the transformation of party participation produced in the last few decades. Two main goals will lead our discussion: on the one hand we will aim to provide a reference overview that can contribute to developing further research on this matter; and on the second hand, we will try to mitigate the segmentation that characterizes the different analytical streams. Reviewing papers published in journals, but also Anglo-Saxon and French books, we get to compare their research problems, their underlying theoretical issues, as well as their specific methods. We will thus identify the structures of two fields in Political Sciences production that barely communicate between each other. First, the mainstream "Political Science" tradition, whose studies favor a systemic and comparative approach, relying on a fundamentally statistical demonstration. On the other hand, a Political Sociology tradition, developed in France and whose analytical perspective is little known at an international level. Influenced by the interactionist paradigm, this kind of research employs the socio-ethnographic method and redirects the focus of analysis to social meso and micro levels. Making a critical assessment of the main contributions of both strands, we point some current trends observed by scholars and we especially insist in the heuristic potential offered by research developed in Political Sociology to add new elements for understanding this phenomenon.

KEYWORDS: political participation; militancy; Cartel Party; Political Science Approach; Political Sociology Approach.

This is an Open Access article distributed under the terms of the Creative Commons Attribution Non-Commercial License which permits unrestricted non-commercial use, distribution, and reproduction in any medium provided the original work is properly cited. 